Dhaka Univ. J. Biol. Sci. 20(2): 163-171, 2011 (July)

\title{
ABUNDANCE AND SEASONAL DIVERSITY OF ZOOPLANKTON IN COASTAL AQUATIC ENVIRONMENTS OF MATHBARIA, BANGLADESH*
}

\author{
Pronob Kumar Mozumder*, M. Niamul Naser, Munirul Alam ${ }^{1}$ \\ AND ANWAR HUQ 2 \\ Advanced Fisheries Research Laboratory, Department of Zoology, \\ Faculty of Biological Sciences, University of Dhaka, Dhaka 1000, Bangladesh
}

Key words: Seasonal diversity, Mathbaria, Zooplankton, Abundance

\begin{abstract}
Monthly seasonal diversity and abundance of zooplankton species at three ponds of Mathbaria were investigated from surface water column during January 2008 to December 2008. Thirty-six species of zooplankton were identified from the ponds. Among these, 25 belonged to rotifer, six were of protozoan, three were copepods and one each from cladocera and ostracoda. Nauplii (copepods) were the most abundant $(39.09 \%$ in site $1,36.81 \%$ in site 2 , and $33.06 \%$ in site 3$)$ group, while the ostracoda were the least abundant $(0.1 \%$ in site 2) group. The relative abundance was maximum (39.09\%) for nauplii and minimum $(4.56 \%)$ for cladocera in site 1; maximum (36.81\%) for nauplii and minimum $(0.1 \%)$ for ostracoda in site 2; maximum $(33.15 \%)$ for rotifer and minimum $(1.17 \%)$ for Cladocera in site 3 . The species of frequent occurrence $(100 \%)$ were Cyclops sp. and copepoda nauplius. In Bangladesh, cholera outbreaks have two major peaks, one between March to May and other between August to October. This study shows that, seasonal diversity and abundance of zooplankton species varied with seasons, the zooplankton peaks coincide to the reported peak outbreak of cholera at the area.
\end{abstract}

\section{Introduction}

In freshwater ecosystem, zooplanktonic organisms which comprise of the second level of the food chain, are important food sources of many invertebrate animals and fish. Some of the zooplankton like rotifers were reported as primary consumers that feed on various phytoplankton while others were reported as raptorial predators that feed on bacteria and detritus matters. ${ }^{(1,2)}$ The main food of major carps like rui, catla and their hybrids were found to be plankton in origin.(3) Besides zooplankton plays an important role in the water quality, eutrophication status and productivity of a lake.(4) The zooplankton in a freshwater pond are those which are caught in a fine-meshed net towed slowly through the water column, and consist mainly of protozoan, rotifers, cladocerans,

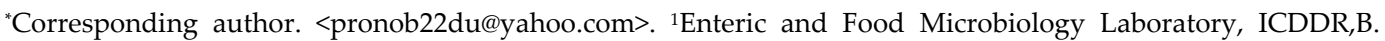
Dhaka. ${ }^{2}$ Maryland Pathogen Research Institute, University of Maryland, USA. *Part of the Ph. D. dissertation of First author (PKM). 
copepods and a great variety of immature larval forms of insects and crustacean ${ }^{(5)}$. Zooplanktons pass a short life-cycle, and thus multicellular zooplankters inhabiting a shallow freshwater body respond quickly to environmental changes, and hence their species composition and frequency of seasons; abundance fluctuate according to the changing environmental status. ${ }^{\left({ }^{6}\right)}$ Zooplankton play an important role as a reservoir of $V$. cholerae which is responsible for seasonal cholera and zooplankton also plays a major role in the multiplication, survival and potential transmission of cholera in coastal water body of Mathbaria.(7) Mathbaria is a cholera prone area and the inhabitants of that area use pond water for drinking, washing, cooking and other social purposes as the salinity of underground water is beyond acceptable level. Thus, in order to find out relationships between zooplankton abundance and cholera disease, it is necessary to observe seasonal diversity and abundance of zooplankton species. The present investigation is an attempt to examine the abundance, seasonal diversity and composition of zooplankton of selected ponds of Mathbaria, Bangladesh.

\section{Materials and Methods}

Mathbaria of Pirozpur district is located adjacent to the Bay of Bengal, approximately $400 \mathrm{Km}$ southwest of Dhaka. The river, Baleshwar, flows along the western boundary of Mathbaria, on its other side a tropical mangrove forest of the Sundarbans is located. In the current study, water samples were collected monthly from three excavated ponds that are exclusively used only water sources for drinking and other restricted domestic uses. No anthropogenic contamination was allowed in the ponds except flood water.

Water samples were collected from three ponds used socially in three different localities of Mathbaria, between January, 2008 to December, 2008. For zooplankton sample collection, 100 liters of water was filtered successively through $64 \mu \mathrm{m}$ mesh nylon nets (Millipore Corp., Bedford, MA), and $50 \mathrm{ml}$ of the concentrates was collected initially as a crude measure of zooplankton. The collected zooplankton samples were fixed in $4 \%$ buffer formaldehyde solution and were identified at the Advanced Fisheries Research Laboratory of Department of Zoology, University of Dhaka.

For qualitative and quantitative study, zooplankton samples were examined under a compound microscope (Axioskop 40, Japan) in a Sedgeweak-Rafter cell. The specimens were identified up to genera or species level. The zooplankton species were identified using various text books. ${ }^{(8-12)}$

\section{Results and Discussion}

Zooplankton collected from the three sites of Mathbaria across seasons were identified. They belong to 36 species (Table 1). Among these, 25 belonged to rotifera, six were of protozoans, three were copepods and one each from cladocera and ostracoda. Nauplii (copepods) were the most abundant $(39.09 \%$ in site $1,36.81 \%$ in site 2 , and 
$33.06 \%$ in site 3) group, while the Ostracoda were the least abundant $(0.1 \%$ in site 2$)$ group. The qualitative zooplankton analysis in Bakerganj showed the presence of 47 taxa from five groups: Protozoa (four taxa), Rotifera (31 taxa), Copepoda (five taxa), Cladocera (five taxa) and Ostracoda (two taxa).(13)

In site 1 , the relative abundance was maximum (33.33\%) for Difflugia sp. and minimum (0.12\%) for Arcella sp., Centropyxis sp. in Protozoa; maximum (5.25\%) for Polyarthra vulgaris and minimum (0.12\%) for Brachionus sp., B. forficula, Colurella sp., Horaella brehmi and Lecane luna in Rotifera; maximum (5.52\%) for Diaptomus sp. and minimum $(2.04 \%)$ for D. gracilis in Copeoda (Table 1$)$.

Furthermore, the frequency of occurrence was maximum (58.33\%) for Difflugia sp. and minimum (8.33\%) for Arcella sp., Glaucoma sp. and Centropyxis sp. In Protozoa; maximum (33.33\%) for Polyarthra vulgaris and minimum (8.33\%) for Brachionus sp., $B$. angularis, B. forficula, Colurella sp., Filinia longiseta, Horaella brehmi and Lecane luna in Rotifera; maximum (83.33\%) for Cyclops sp. and minimum (58.3\%) for D. gracilis in Copepoda. Nevertheless, the frequency of occurrence in Cladocera was 58.33\% (Table 1).

In site 2 , the relative abundance was maximum (11.66\%) for Difflugia sp. and minimum (0.1\%) for Glaucoma sp., Centropyxis sp., in Protozoa; maximum (8.01\%) for Pompholyx sulcata and minimum $(0.1 \%)$ for Manfredium sp., Monostyla bula, and Trichocerca sp. in Rotifera; maximum (10.65\%) for Cyclops sp. and minimum (2.64\%) for Diaptomus sp. in Copeoda (Table 1).

Furthermore, the frequency of occurrence was maximum (58.33\%) for Difflugia sp. and minimum (8.33\%) for Glaucoma sp. and Centropyxis sp. in Protozoa; maximum $(41.67 \%)$ for Polyarthra vulgaris, Horaella brehmi and minimum $(8.33 \%)$ for Filinia terminalis, Keratella tropica, Manfredium sp., Monostyla bula, Trichocerca sp., and Testudinella patina in Rotifera; maximum (100\%) for Cyclops sp. and minimum (25\%) for D. gracilis in Copepoda. Nevertheless, the frequency of occurrence in Cladocera was $50 \%$ and Ostracoda was $8.33 \%$ (Table 1 ).

In site 3, the relative abundance was maximum (18.73\%) for Difflugia sp. and minimum $(0.17 \%)$ for Glaucoma sp. in Protozoa; maximum $(8.58 \%)$ for Polyarthra vulgaris and minimum $(0.08 \%)$ for Brachionus angularis, B. diversicornis, B. quadridentatus, Filinia terminalis, Manfredium sp. and Monostyla bula in Rotifera; maximum (6.41\%) for Cyclops sp. and minimum (0.5\%) for D. gracilis and Diaptomus sp. in Copeoda (Table 1$)$.

Furthermore, the frequency of occurrence was maximum $(66.67 \%)$ for Difflugia sp., Phacus sp. and minimum (8.33\%) for Glaucoma sp. and Centropyxis sp. in Protozoa; maximum (41.67\%) for Brachionus falcatus, Horaella brehmi and minimum (8.33\%) for $B$. angularis, B. diversicornis, B. quadridentatus, Filinia terminalis, Keratella tropica, Manfredium sp., Monostyla bula, Pompholyx sulcata and Rotaria neptunia in Rotifera; maximum (91.67\%) for Cyclops sp. and minimum (8.33\%) for D. gracilis in Copepoda. Nevertheless, the frequency of occurrence in Cladocera was 25\% (Table 1). 


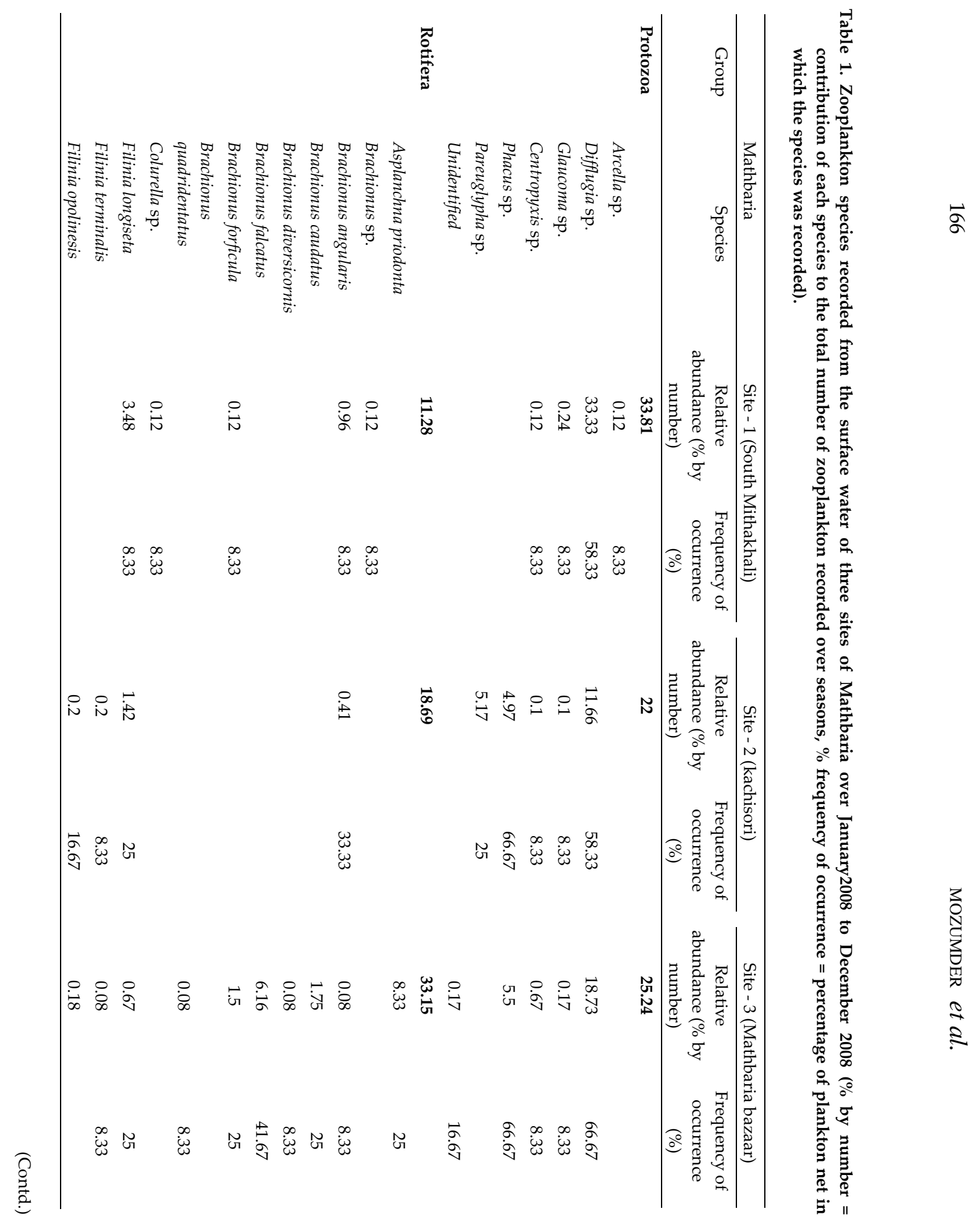




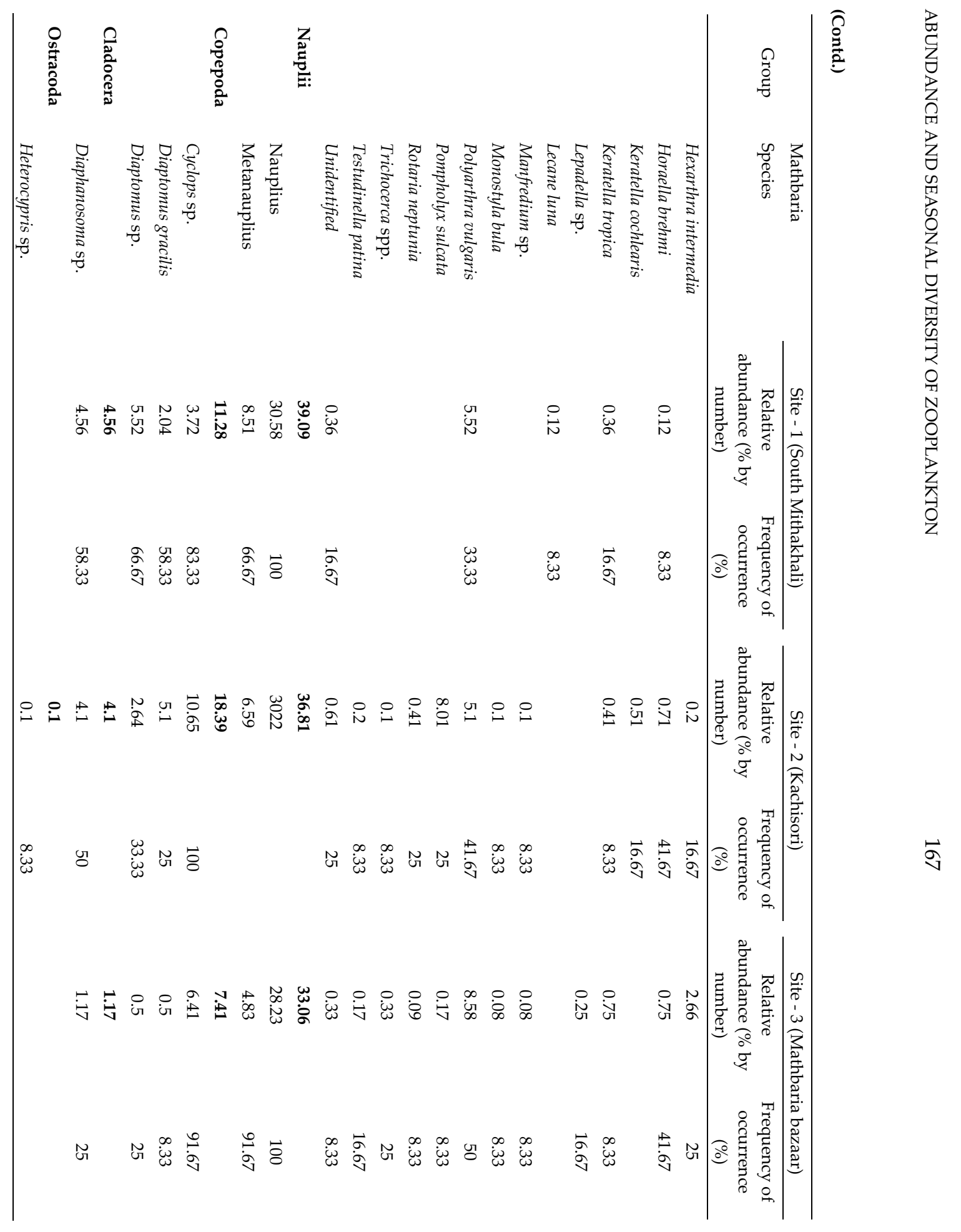


In site 1, the seasonal assemblages of zooplankton species were maximum in August for Protozoa, December for Rotifera, September for copepoda and April for Cladocera (Fig. 1). In contrast, the seasonal assemblages of zooplankton species were minimum in April for Protozoa, August for Rotifera, February, July and August for Copepoda and February for Cladocera. Furthermore, the sum of the assemblages of the zooplankton species was maximum (645 ind/l) in August and minimum (42 ind/l) in March, 2008.

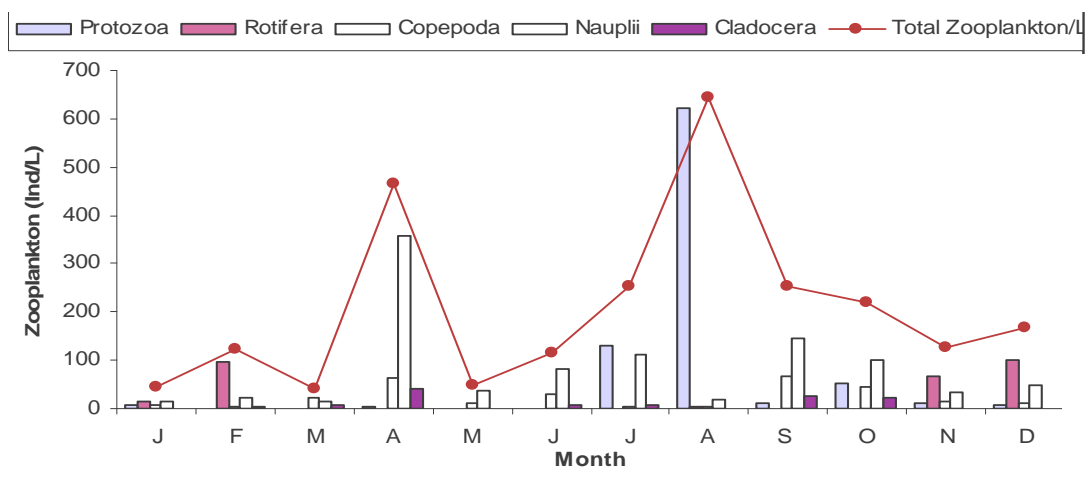

Fig. 1. The zooplankton groups across seasons in surface water of site-1 of Mathbaria.

In site 2, the seasonal assemblages of zooplankton species were maximum in September for Protozoa, February for Rotifera, April for copepoda and April for Cladocera (Fig. 2). In contrast, the seasonal assemblages of zooplankton species were minimum in January for Protozoa, May and August for Rotifera, January, June and July for Copepoda, and November, December for Cladocera. Furthermore, the sum of the assemblages of the zooplankton species was maximum (813 ind/l) in April and minimum (18 ind/l) in January, 2008.

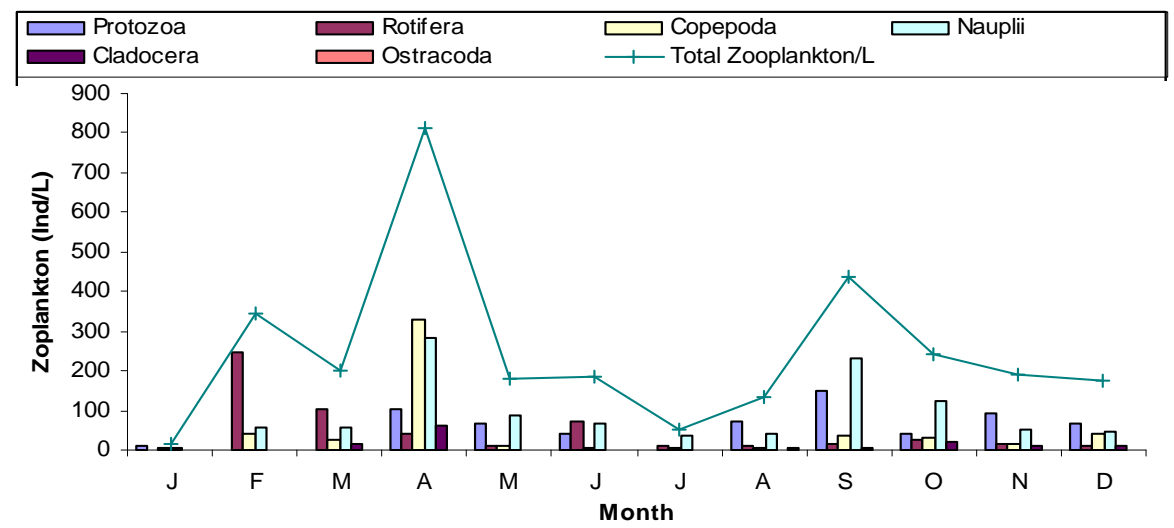

Fig. 2. The zooplankton groups across seasons in surface water of site-2 of Mathbaria. 
In site 3, the seasonal assemblages of zooplankton species were maximum in April for Protozoa, January for Rotifera, Copepoda and Cladocera (Fig. 3). In contrast, the seasonal assemblages of zooplankton species were minimum in March and May for Protozoa, May for Rotifera, September for Copepoda, and April, December for Cladocera. Furthermore, the sum of the assemblages of the zooplankton species was maximum (744 Ind/1) in April and minimum (21 ind/l) in March 2008.

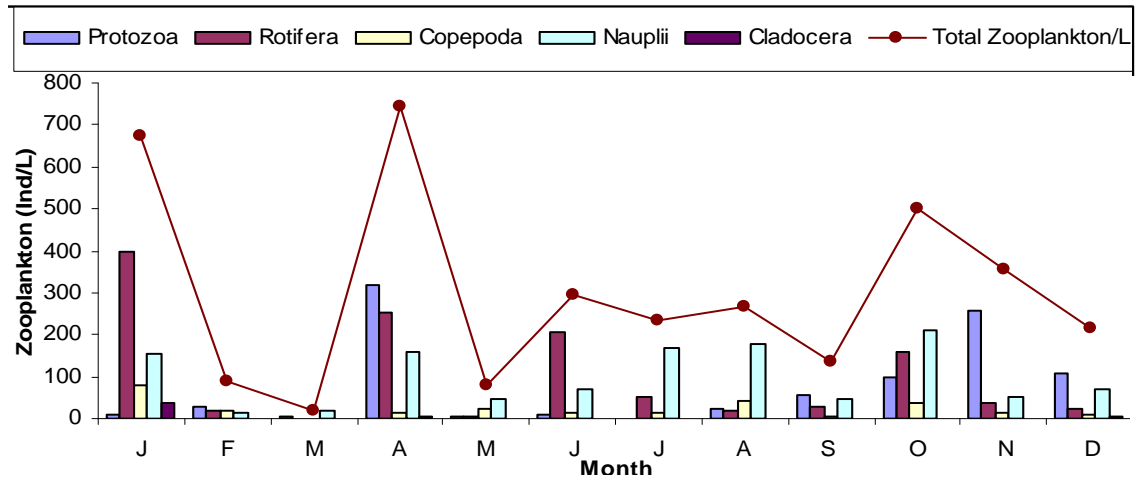

Fig. 3. The zooplankton groups across seasons in surface water of site-3 of Mathbaria.

The protozoa, rotifera, copepoda, cladocera, nauplii and ostracoda mainly constituted the zooplankton groups of studied coastal ponds. The zooplankton species increased their abundance during summer (April-May), probably corresponding to the water quality, decaying vegetation, increased levels of nutrient in the sediment and higher abundance of bacteria in the pond during this time. ${ }^{(14,15)}$ In contrast, the abundance of zooplankton species decreased in winter (November-January), probably corresponding to low water temperature and high alkalinity ( $\mathrm{pH} 7.6$ - 9.8).(16)

The Protozoan populations were fewer in the studied pond surface water. The rotifer populations, however, were more abundant than other zooplankton groups in the all three pond sites of Mathbaria, and this was probably because of their ability to withstand and survive in varying limnological conditions prevailing at different seasons.

Some species (e.g., Cyclops sp., Diaptomus sp., D. gracilis, nauplius larva, metanauplius larva Difflugia sp., Phacus sp., Polyarthra vulgaris, Brachionus angularis, Horaella brehmi, Brachionus falcatus) were more abundant than other zooplankton species, and consequently their frequency of occurrence reached the maximum (30 - 100\%)

Results of the present investigation demonstrated that the seasonal zooplankton diversity decreased in November and December for all three sites. In contrast, the zooplankton diversity reached the peak in April for all sites and August, September and October for all sites. This could influence the abundance of Vibrio cholerae in the aquatic system. 
In Bangladesh, cholera outbreaks have two major peaks, one between March and May and other between August and October.(17) This study shows that, seasonal diversity and abundance of zooplankton species varied with seasons and that the zooplankton peak coinside to the outbreak of cholera in the area.

\section{Acknowledgements}

The research as an integral part of the major multidisciplinary project entitled 'Epidemiology and Ecology of Vibrio cholerae in Bangladesh' was financed by the National Institute of Health (NIH) research grant \# 1RO1A13912901 under the collaborative agreement between the International Center for Diarrhoeal Disease Research, Bangladesh (ICDDR, B) and Johns Hopkins Bloomberg School of Public Health. The authors gratefully acknowledge the NIH Ecological Surveillance Team at ICDDR, B for kindly supporting this research. The authors are also grateful to Kaji Tamanna Keya, Research Officer, Population Council, Dhaka, for her assistance during the research.

\section{References}

1. Boulin VV, VN Nikulina, EB Paveljeva and LA Stepanova 1999. Microbial loop in trophic food web of lake plankton. J. General Biol. 60: 431-444.

2. Hakanson L, VV Boulin and A Ostapenia 2003. The influence of biomanipulations (fish removal) on the structure of lake food web, case studies using Lake Web - model. Aqua. Ecol. 37: 47-68.

3. Mozumder PK and MN Naser 2009. Food and feeding habit of Catla (Catla catla .Ham.),Rui (Labeo rohita Mam.) and catla - rui hybrids. Bangladesh J. Zool. 37(2): 303-312.

4. Mikschi E 1989. Rotifer distributions In Relation to temperature and oxygen content. Hydrobiol. 186/187: 209-214.

5. Odum E P 1971. Fundamentals of Ecology. $3^{\text {rd }}$ edition, W.B. Saunders Company, Philadelphia, pp. 574.

6. Ganon JE and RS Stemberger 1978. Zooplankton (especially crustaceans and rotifers) as indicators of water quality. Trans .Amer.Micros. Soc. 97: 1-16.

7. Huq A, MAR Chowdhury, MS Islam, R Montilla and RR Colwell 1996. A simple Filtration Method to Remove Plankton - Associated Vibrio cholerae in raw water supplies in developing countries. Appl. Environ. Microbiol. 62(7): 2508-2512.

8. Ali S and T Chakraborti 1992. A Book on Freshwater Invertebrate of Bangladesh. In Bengali, Bangla Academy. Dhaka. pp. 252.

9. Bhouyain A M and GSM Asmat 1992. Freshwater Zooplankton from Bangladesh. Ghazi Publishers. Dhaka-1100. pp. 197.

10. Mellanby H 1971. Animal life in Fresh water. Chapman and Hall. London. pp. 308.

11. Edmonson WT 1959. Fresh water biology. $2^{\text {nd }}$ edn., John Wiley and Sons Inc. New York. pp. 1246.

12. Tonapi GT 1980. Fresh water animal in India. Oxford and IBN publishing co. New Delhi. pp. 538. 
13. Mozumder PK, MN Naser, MS Ali, M Alam, A Huq, RB Sack and RR Colwell 2010. Qualitative and quantitative analysis of zooplankton of some coastal water bodies of Bakerganj, Bangladesh. Bangladesh J. Zool. 38(1): 127-132.

14. Jacoby CA and JG Greenwood 1989. Emergent zooplankton in Moreton Bay, Queensland,Australia:seasonal,lunar and diel paterns in emergences and distribution with respect to substrata. Marin Ecology Progress Series 51: 131-154.

15. Srivastava KN, P Srivastava and AK Sinha 1990. Zooplankton studies of Ganga river between Kalkanker (Pratapgarh) and Phaphamau (Allahabad). Recent Trends in Limnology 1-4: 129-133.

16. Chattopadhyay C and TC Banerjee 2007. Temporal changes in environmental characteristics and diversity of net-phytoplankton in a freshwater lake. Turk. J. Bot. 31: 287-296.

17. Alam M, NA Hasan, A sidique, NA Bhuiyan, KU Ahmed, S Nasrin, GB Nair, AK Siddique, RB Saek, DA Saek, A Huq and R Colwell. 2006. Seasonal cholera caused by Vibrio cholarae sesogroups $\mathrm{O} 1$ and $\mathrm{O} 139$ in the coastal squatic environment of Bangladesh. Applied and Environment. Microbiol. 72(6): 4096-4104.

(Manuscript received on 10 November, 2010; revised on 28 December, 2010) 